\author{
Дьяченко Ю.В. \\ к.е.н.,старший викладач \\ кафедра менеджменту та логістики \\ Одеська національна академія харчових технологій \\ вул. Канатна, 112, м. Одеса, Україна, 65039 \\ E-mail: ypogarchuk@gmail.com \\ ORCID ID: 0000-0002-8754-3256
}

\title{
АНАЛІЗ ВПЛИВУ МАКРОФАКТОРІВ ЗОВНІШНЬОГО СЕРЕДОВИЩА НА ДІЯЛЬНІСТЬ М'ЯСОПЕРЕРОБНИХ ПІДПРИЄМСТВ УКРАЇНИ
}

В статті розглянуто стан та динаміку змін макрофракторів зовнішнього середовища, які здійснюють вплив на діяльність м'ясопереробних підприємств України. Серед основних політико-правових фракторів виявлено: - втрата територіальної цілісності та через це втрата виробничих потужностей і ринків збуту, криза у відносинах з Російською Федерацією, - підписання Угоди про асоціацію з ЄС за продовження євроінтеграційних процесів, - обов'язкове впровадження системи НАССР на м'ясопереробних підприємствах тощо. До економічних факторів слід віднести: - скасування спецрежиму оподаткування підприємств, що займаються розведенням тварин та виробництвом м'яса, - девальвація національної валюти, - низька купівельна спроможність населення, - високий індекс інфляції, - тенденція до скорочення ринку м'яса і м'ясопродуктів. Дослідження соціально-демографічного фактору дало змогу виявити: - зменшення чисельності населення, - висока частка людей похилого віку в віковій структурі населення, - відтік висококваліфрікованих кадрів з вищою освітою за кордон. Технологічний фактор можна охарактеризувати таким чином: - низький рівень інноваційної активності підприємств харчової промисловості, - слабке фрінансування інноваційної діяльності підприємств державою, - здійснюється розробка нових видів продукції та технологічних процесів. Для систематизації описаних макрофакторів використано методику побудови матриці PESTаналізу.

Ключові слова: м'ясопереробна галузь України, м'ясопереробні підприємства, зовнішнє середовище, макрофактори.

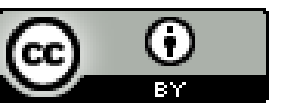

This work is licensed under a Creative Commons Attribution 4.0 International License http://creativecommons.org/licenses/by/4.0/
Постановка проблеми та її зв'язок з важливими науковими та практичними завданнями. Сучасні мінливі умови функціонування м'ясопереробних підприємств України спонукають до детального аналізу стану та динаміки змін макрофакторів зовнішнього середовища, що впливають на їх діяльність, а саме: політико-правового, економічного, соціальнодемографічного та технологічного факторів. Це $\epsilon$ необхідною умовою для подальшого розвитку м'ясопереробних підприємств шляхом розробки ефективної стратегії зростання чи стабілізації.

Аналіз останніх публікацій по проблемі. В ринковій економіці кожне підприємство, в тому числі і м'ясопереробне, функціонує в певному конкурентному середовищі. Аналіз робіт авторів М. Портера [1], А. Томпсона та А. Дж. Стрікленда [2], I. Ансоффа [3], Ф. Котлера [4], Ж-Ж Ламбена [5], Р. Фатхутдінова [6], В. Павлової [7], Л. Балабанової [8] показав, що залежно від наукових поглядів автори по-різному обгрунтовують комплекс факторів, що впливають на діяльність підприємства. Науковці виділяють величезну кількість факторів, які сприяють ефективності функціонування підприємства чи послаблюють ії. Дані фактори класифікують: залежно від місця виникнення, за тривалістю дії, залеж- но від сфери походження, залежно від ступеню корисності, залежно від рівня взаємообумовленості, за ступенем можливого контролюючого впливу з боку держави i підприємства, за характером спеціалізації [9]. На нашу думку, подальшого розгляду потребує практичний аспект, а саме вплив макрофакторів зовнішнього середовища на діяльність м'ясопереробних підприємств України.

Формулювання цілей дослідження. Метою даного дослідження є аналіз стану та характеру впливу політико-правового, економічного, соціальнодемографічного, технологічного макрофакторів на діяльність м'ясопереробних підприємств України.

Виклад основних результатів та їх обгрунтування. Системний аналіз макрофакторів зовнішнього середовища створює необхідну інформаційну базу для формування та реалізації ефективних стратегічних альтернатив націлених на подальший успішний розвиток підприємства на ринку. Таким чином, необхідно проаналізувати стан та характер впливу політикоправового, економічного, соціально-демографічного, технологічного макрофакторів.

Політико-правовий фактор. Політична ситуація в країні нестабільна, так з 2014 року відбулася анек- 
сія Автономної Республіки Крим, також на території Донецької та Луганської областей проводиться операція Об'єднаних сил (ООС) і частина територій цих областей $€$ непідконтрольними Україні. Значно змінилась картина зовнішніх відносин зі світовою спільнотою: критичне погіршення відносин з Російською Федерацією, покращення $з$ країнами Європейського союзу та США, зміцнення відносин 3 країнами Азії, налагодження більш продуктивної взаємодії з країнами Африки. Це має вплив на напрямки та масштаби зовнішньоекономічної діяльності м'ясопереробних підприємств, що було досліджено нами раніше.

Членство в СОТ і подальший євроінтеграційний процес після підписання 1 вересня 2017 р. Угоди про асоціацію між Україною та Свропейським Союзом вимагає від суб'єктів господарювання застосування міжнародних стандартів та норм ведення бізнесу. Це стосується як питань регулювання якості, так і безпечності продукції. В Україні безпечність харчової продукції регулюється такими документами: технічні регламенти, стандарти, санітарні правила і норми, Постанови Кабінету міністрів України, накази відповідних міністерств та відомств. Поняття «безпечність» $є$ базовим у системі управління ризиками підприємств харчової галузі (Hazard Analysis and Critical Control Points) [10]. В Україні загальнодержавну концепцію впровадження принципів НАССР передбачає Закон України «Про основні принципи та вимоги до безпечності та якості харчових продуктів» [11]. Контроль за виконанням норми Закону підприємствами-виробниками згідно Постанови КМУ № 667 від 02.09.2015 р. покладено на Державну службу України $з$ питань безпечності харчових продуктів та прав споживачів [12]. Слід зазначити, що впровадження системи НАССР $є$ необхідним заходом для забезпечення конкурентоспроможності м'ясопереробних підприємств України на внутрішньому та зовнішньому ринках.

В ході дослідження виявлено, що існує проблема стандартизації у вітчизняній м'ясній промисловості. В даний час підприємства працюють, як за загальнодержавними стандартами (ДСТУ), так і за технічними умовами (ТУ), розробленими самими виробниками i затвердженими місцевими відділеннями органів стандартизації. Вироби, що виготовлені за ДСТУ, відповідають жорстким вимогам та мають більш високу ціну, ніж так званий нетрадиційний «європейський» асортимент, що виготовлений за ТУ. Для захисту споживачів від недобросовісної конкуренції з 01.08.2016 р. було прийнято ДСТУ 7680:2015 «Продукти м'ясні та вироби м'ясомісткі. Номенклатура та вимоги до назв». Тепер номенклатура ковбас і сосисок, вимога до їх назв повинна чітко визначатися, це або «продукти м'ясні» або «продукти м'ясовмісні».

Економічний фактор впливає на діяльність м'ясопереробних підприємств через державну підтримку галузі. Нещодавно відбулися зміни в державній політиці: відтепер підприємства, що займаються розведенням ВРХ та буйволів, коней та тварин родини конячих, вівець і кіз, свиней, свійської птиці, інших тварин та виробництвом м'яса замість автоматичного механізму повернення ПДВ користуються бюджетними дотаціями, що зменшує обсяги державної підтримки. Бюджетна дотація надається товаровиробникам, які провадять види діяльності, визначені у Законі України «Про державну підтримку сільського господарства України» [13]. Дотації виплачує Аграрний фонд у порядку, визначеному Кабінетом міністрів України. Цей порядок визначає механізм розподілу коштів, передбачених Міністерством аграрної політики та продовольства України у державному бюджеті за програмою 2801580 «Фінансова підтримка сільгосптоваровиробників».

Потрібно також відмітити негативний процес девальвації національної валюти, що негативно впливає як на економічну ситуацію в країні в цілому, так і на діяльність м'ясопереробних підприємств зокрема. За даними Міністерства фінансів України, курс гривні по відношенню до долара в 2012 р. був 7,98 грн, 2013 р. 8,08 грн, 2014 р. - 8,32 грн, 2015 р. - 15,76 грн, 2016 р. 24,0 грн, 2017 р. - 27,2 грн [14].

Одним з основних економічних факторів, що вливає на обсяг попиту і пропозиції м'яса і м'ясопродуктів $є$ купівельна спроможність населення. Вона залежить, насамперед, від ціни товару та доходу споживача. Ціни на продукцію щорічно зростають приблизно на 20 \% через збільшення собівартості (зростання цін на сировину та енергоресурси, витрат на оновлення основних виробничих фондів та збільшення фонду заробітної плати).

Проаналізуємо рівень заробітної плати і пенсійних виплат в Україні (табл. 1). Як видно з таблиці, номінальна заробітна плата в 2016 р. перевищує прожитковий мінімум в 3,9 разів, а пенсія лише в 1,3 рази.

Таблиця 1

Рівень заробітної плати і пенсійних виплат в Україні за 2011-2016 рр. *

\begin{tabular}{|c|c|c|c|c|c|c|}
\hline \multirow{2}{*}{ Рік } & \multirow{2}{*}{$\begin{array}{c}\text { Номінальна } \\
\text { заробітна } \\
\text { плата, грн }\end{array}$} & \begin{tabular}{c} 
Відсотків до попереднього року \\
\cline { 3 - 4 }
\end{tabular} & $\begin{array}{c}\text { індекс } \\
\text { номінальної } \\
\text { заробітної } \\
\text { плати }\end{array}$ & $\begin{array}{c}\text { Роздір } \\
\text { реальної } \\
\text { заробітної } \\
\text { пінімальної } \\
\text { заробітної } \\
\text { плати, грн }\end{array}$ & $\begin{array}{c}\text { Середній розмір } \\
\text { місячної пенсії } \\
\text { (за даними } \\
\text { Пенсійного фон- } \\
\text { ду України), грн }\end{array}$ & $\begin{array}{c}\text { Прожитковий } \\
\text { мінімум, грн }\end{array}$ \\
\hline 2011 & 2633 & 117,6 & 108,7 & 1004 & 1151,9 & 894 \\
\hline 2012 & 3026 & 114,9 & 114,4 & 1073 & 1253,3 & 1071 \\
\hline 2013 & 3265 & 107,9 & 108,2 & 1147 & 1470,7 & 1108 \\
\hline 2014 & 3480 & 106 & 93,5 & 1218 & 1526,1 & 1176 \\
\hline 2015 & 4195 & 120,5 & 79,8 & 1218 & 1581,5 & 1176 \\
\hline 2016 & 5183 & 123,6 & 109 & 1378 & 1699,5 & 1330 \\
\hline
\end{tabular}

*складено автором на основі [15] 
Аналіз структури грошових доходів домогосподарств в 2016 р. показав, що оплата праці займає частку 54,3 \%; доходи від підприємницької діяльності та самозайнятості $6 \%$; доходи від продажу сільськогосподарської продукції 3,5 \%; пенсії, стипендії, допомоги та субсидії надані готівкою 26,8 \%; грошова допомога від родичів та інших осіб і інші доходи складають 9,4 \%.

Проведений аналіз рівня еквівалентних грошових доходів на душу населення в 2016 р. показав, що частка населення із доходами, нижчими законодавчо встановленого прожиткового мінімуму становить 10,2 \%. Все це свідчить про низьку купівельну спроможність населення. Саме тому постає питання аналізу впливу цінового фактору на зміну обсягу споживання м'яса та м'ясопродуктів. Для вирішення цього питання нами досліджена динаміка темпів приросту обсягу споживання м'яса та м'ясопродуктів та темпів інфляції на ринку споживчих товарів, зокрема м'яса та м'ясопродуктів (табл. 2).

Таблиця 2

Динаміка основних економічних показників, що характеризують стан ринку м'яса і м'ясопродуктів України у 2012-2016 рр. (у \% до попереднього періоду)*

\begin{tabular}{|l|c|c|c|c|c|}
\hline \multicolumn{1}{|c|}{ Показник } & 2012 p. & 2013 p. & 2014 p. & 2015 p. & 2016 p. \\
\hline Індекс споживчих цін & 99,8 & 100,5 & 124,9 & 143,3 & 112,4 \\
\hline Темп приросту споживчих цін & - & 0,70 & 24,28 & 14,73 & $-21,56$ \\
\hline Індекс цін на продукцію харчування & 97,1 & 99,2 & 124,5 & 140,1 & 103,2 \\
\hline Темп приросту цін на продукцію харчування & - & 2,16 & 25,50 & 12,53 & $-26,34$ \\
\hline Індекс цін на м'ясо і мясопродукти & 101,3 & 96,9 & 127,5 & 122,5 & 105 \\
\hline Темп приросту цін на м'ясо і мясопродукти & - & $-4,34$ & 31,58 & $-3,92$ & $-14,29$ \\
\hline Споживання м'яса на 1 особу, кг & 54 & 56 & 54 & 51 & 51 \\
\hline Темп приросту споживання & - & 3,70 & $-3,57$ & $-5,56$ & 0,00 \\
\hline
\end{tabular}

*складено автором на основі [14]

Отже, ми бачимо досить високий рівень інфляції в країні і зростання цін на продукцію харчування, зокрема на м'ясо і м'ясопродукти, що супроводжується низькою купівельною спроможністю населення.

Структура витрат домогосподарств в 2016 р. складається на 53,1 \% 3 витрат на продовольчі товари, $38,4 \%$ - витрати на непродовольчі товари та послуги, $3,2 \%$ - грошова допомога родичам та іншим особам, 5,3 $\%$ - інші витрати. Сучасною економічною наукою доведено, що значення частки витрат на продовольчі товари вище $50 \%$ свідчить про низький життєвий рівень населення і є одним із індикаторів бідності [15].
Соціально-демографічний фактор також впливає на ємність ринку та рівень попиту на продукцію м'ясопереробних підприємств України. Так, обсяг реалізації в значній мірі залежить від чисельності населення. За даними Державної служби статистики України чисельність населення України в 2016 р. порівняно 3 2011 р. скоротилась на 3,0 млн. осіб або на 6,55 \% і становить 42,8 млн. осіб, а порівняно з 2001 р. коли проводився Всеукраїнський перепис і чисельність складала 48,9 млн. осіб - на 12,47 \%. Отже, чисельність населення скорочується щороку. Це пов'язано перш за все із співвідношенням живонароджених та померлих (табл. 3).

Таблиця 3

Кількість живонароджених, померлих та природний приріст (скорочення) населення*

\begin{tabular}{|l|c|c|c|c|c|c|}
\hline \multicolumn{1}{|c|}{ Показник } & 2011 p. & 2012 p. & 2013 p. & 2014 p. & 2015 p. & 2016 p. \\
\hline Кількість живонароджених & 502,6 & 520,7 & 503,7 & 465,9 & 411,8 & 397 \\
\hline Кількість померлих & 664,6 & 663,1 & 662,4 & 632,3 & 594,8 & 583,6 \\
\hline Природний приріст/скорочення населення & $-162,0$ & $-142,4$ & $-158,7$ & $-166,4$ & $-183,0$ & $-186,6$ \\
\hline
\end{tabular}

* складено автором на основі [15]

Зниження рівня народжуваності призвело до того, що сьогодні близько $30 \%$ населення - пенсіонери. Структура населення за віком виглядає таким чином: частка осіб від 1 до 19 років - 19,8 \%, 20 до 49 років $43,3 \%, 50$ до 64 років - 20,6 \%, 65 років і старше - 16,3 $\%$. Сучасну демографічну ситуацію можна визначити як кризову ще й тому, що депопуляція супроводжується істотним погіршенням здоров'я людей, що виявляється у зниженні середньої тривалості життя. На сьогодні середня очікувана тривалість життя при народженні (для обох статей) в Україні становить 68,6 років $(62,8$ років - чоловіки, 74,8 років - жінки) [15].

Технологічний фактор. За даними Державної служби статистики України в 2015 р. виробництвом харчових продуктів, напоїв і тютюнових виробів займалися 984 підприємства, з яких інноваційною діяльністю займалися 178 підприємств або 18,09 \%. Це 21,60 \% від усіх промислових підприємств, що здійснювали інноваційну діяльність. Придбання машин, обладнання та програмного забезпечення здійснили 92 підприємства, внутрішніми НДР займались 13 підприємств, зовнішніми НДР - 7 підприємств, придбали інші зовнішні знання 
(придбання нових технологій) - 6 підприємств, та 45 підприємств займались навчанням та підготовкою персоналу для розробки та запровадження нових або значно вдосконалених продуктів та процесів, діяльністю щодо ринкового запровадження інновацій та іншими роботами, що пов'язані зі створенням та впровадженням інновацій [16].

3 досліджуваних 178 підприємств впроваджували інноваційні процеси 85 підприємств і це 116 впроваджених нових технологічних процесів (з них маловідходні, ресурсозберігаючі - 41); впроваджували інноваційні види продукції 93 підприємства і це 455 найменувань продукції (з них нові для ринку - 68).

Протягом 2015 р. на інновації досліджувані підприємства витратили 1540,3 млн. грн., в т. ч. за напрямами інноваційної діяльності: «на придбання машин, обладнання та програмного забезпечення - 1328,4 млн. грн. (86,2 \% від усіх витрат), на внутрішні та зовнішні науково-дослідні розробки - 86,3 млн. грн. (5,6 \%), на придбання інших зовнішніх знань (придбання нових технологій $)$ - 1,2 млн. грн (0,1 \%) та 124,3 млн. грн. $(8,1$ $\%)$ - на навчання та підготовку персоналу для розробки та запровадження нових або значно вдосконалених про- дуктів та процесів, діяльність щодо ринкового запровадження інновацій та інші роботи, пов'язані зі створенням та впровадженням інновацій (інші витрати)» [16].

Основним джерелом фінансування інноваційних витрат підприємств, що займаються виробництвом харчових продуктів, напоїв і тютюнових виробів $є$ власні кошти - 95,9 \% від загального обсягу витрат на інновації, кошти державного бюджету і місцевих бюджетів $0,02 \%$, кошти іноземних інвесторів - 1,6 \%, кредити $4,01 \%[16]$.

Серед вагомих причин, що уповільнюють інноваційні процеси в країні $є$ : відсутність достатнього обсягу коштів (власних, залучених, позикових); кваліфікованих працівників в межах підприємства; труднощі в отриманні державної допомоги або субсидій для інновацій; відсутність партнерів по співпраці; невизначений попит на інноваційні ідеї; занадто велика конкуренція на ринку.

Для систематизації описаних макрофакторів зовнішнього середовища, які впливають на діяльність м'ясопереробних підприємств, використано методику побудови матриці PEST-аналізу (табл. 4).

Таблиця 4

Матриця PEST- аналізу*

\begin{tabular}{|c|c|c|}
\hline$P$ & ПОЛІТИКА & KA \\
\hline & 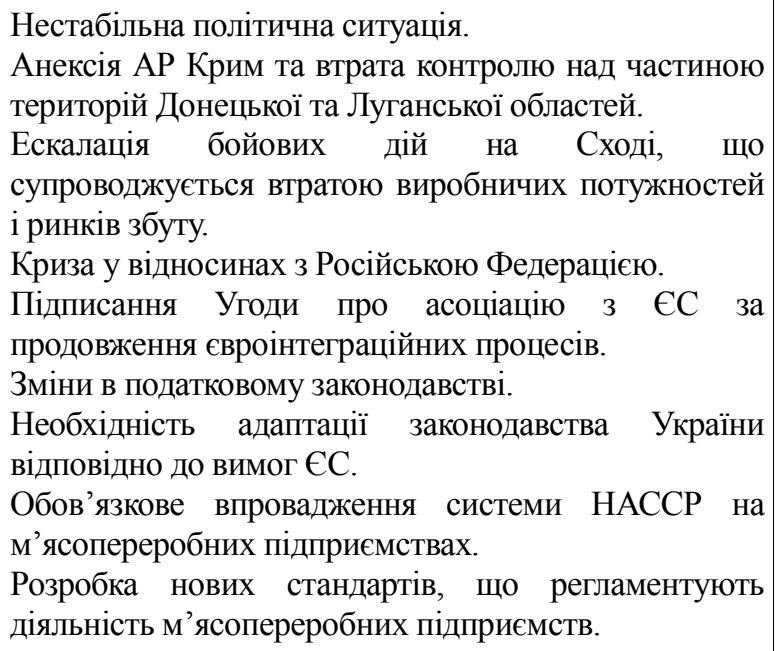 & $\begin{array}{ll}\text { 1. Скасування спецрежиму оподаткування } \\
\text { підприємств, що займаються розведенням тварин } \\
\text { та виробництвом м'яса (надається бюджетна } \\
\text { дотація). } \\
\text { 2. Девальвація національної валюти. } \\
\text { 3. Низька купівельна спроможність населення. } \\
\text { 4. Високий рівень безробіття. } \\
\text { 5. Високий індекс інфляції. } \\
\text { 6. Скорочення реальних доходів населення. } \\
\text { 7. Продовольче ембарго з боку Російської Федерації } \\
\text { 8. Наявність квоти на експорт в ЄС м'яса вітчизняно- } \\
\text { го виробництва, що звільнястья від сплати мита. } \\
\text { 9. Активізація Азійського та Африканського напряму } \\
\text { в ЗЕд. } \\
\text { 10. Тенденція до скорочення ринку м'яса і } \\
\text { м'ясопродуктів. }\end{array}$ \\
\hline S & СОЦІУМ & ТЕХНОЛОГІЯ \\
\hline & 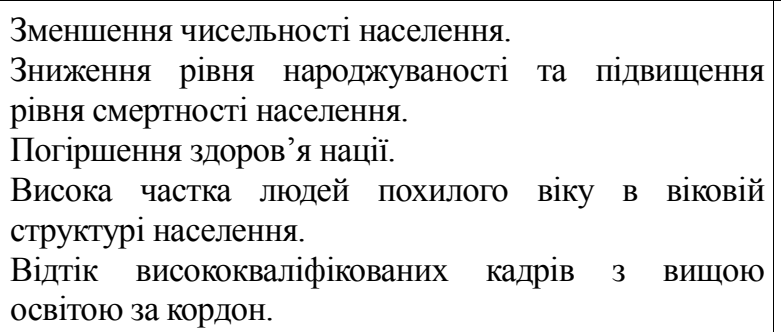 & \begin{tabular}{ll} 
1. Низький рівень інноваційної & \multicolumn{2}{l}{ активності } \\
& $\begin{array}{l}\text { підприємств харчової промисловості } \\
\text { підприємств). }\end{array}$ \\
2. Слабке фінансування інноваційної діяльності \\
підприємств державою. \\
3. \\
3дійснюється розробка нових видів продукції. \\
Здійснюється розробка нових технологічних \\
процесів (маловідходних, ресурсозберігаючих).
\end{tabular} \\
\hline
\end{tabular}

\section{*розроблено автором}

Висновки та перспективи подалыших досліджень. Узагальнення результатів дослідження дало можливість визначити стан законодавчої та нормативнотехнічної документації, що регламентує діяльність м'ясопереробних підприємств, іії відповідність міжнародними стандартам, а також вимогам СС в сфері регулю- вання безпечності та якості харчових продуктів; механізм державної підтримки галузі через виплату бюджетних дотацій; сила національної валюти; купівельна спроможність населення; проаналізовано соціальнодемографічний фактор; рівень розвитку інноваційної діяльності на харчових підприємствах, 
в т.ч. м'ясопереробних. Таким чином, нами було проаналізовано вплив розглянутих макрофакторів на діяльність м'ясопереробних підприємств України. Подальші дослідження передбачають обгрунтування ефективних стратегій розвитку м'ясопереробних підприємств на внутрішньому і зовнішньому ринках.

\title{
Література
}

1. Портер М. Конкуренция: пер. с англ. Москва: ИД "Вильямс", 2010. 591 с.

2. Томпсон А.А., Стрикленд А.Дж. Стратегический менеджмент / Томпсон А.А., Стрикленд А.Дж.; пер. с англ. Москва: ИД "Вильямс", 2009. 307 с.

3. Игорь Ансофф: Стратегическое управление // Гуманитарные технологии: [Веб-сайт]. Москва, 2019 г. URL: https:/gtmarket.ru/laboratory/basis/4155 (дата обращения: 01.08.2019).

4. Котлер Ф. Маркетинг менеджмент / Котлер Ф.; пер. с англ. под ред. С. Г. Божук. СПб: Питер, 2011. 464 с.

5. Ламбен Ж-Ж. Стратегический маркетинг / Ламбен Ж-Ж.; пер. с франц. СПб: Наука, 1996. 589 с.

6. Фатхутдинов Р.А. Управление конкурентоспособностью организации. Москва: Эксмо, 2004. 544 с.

7. Павлова В.А. Конкурентоспроможність підприємства: оцінка і стратегія забезпечення: монографія. Д: ДУЕП, 2006. $276 \mathrm{c.}$

8. Балабанова Л.В., Кривенко А.В. Управление конкурентоспособностью предприятий на основе маркетинга: монография. Д: Дон ГУЭТ им. М. Туган-Барановского, 2004. 147 с.

9. Пожарчук Ю.В. Фактори, що впливають на конкурентоспроможність підприємства // Актуальні досягнення європейської науки - 2012, секція «Економічні науки»: матеріали VIII міжнар. наук.-практ. конф., Софія, 1725 червня 2012 р. / Софія, 2012. С. 90-91.

10. Дьяченко Ю.В. Правове забезпечення конкурентоспроможності продукції м'ясопереробних підприємств України на європейському ринку // Економіка харчової промисловості. 2017. Т. 9, вип. 4. С. 43-48. doi: 10.15673/fie.v9i4.742

11. Про основні принципи та вимоги до безпечності та якості харчових продуктів: Закон України № 771/97BP за станом на 06.08.2019 р. // Верховна Рада України "Законодавство України": [Веб-сайт]. Київ, 2019 р. URL: https://data.rada.gov.ua/laws/show/771/97-вр (дата звернення: 5.08.2019).

12. Про затвердження Положення про Державну службу України з питань безпечності харчових продуктів та захисту споживачів: Постанова КМУ №667 за станом на 30.03.2019 р. // Верховна Рада України "Законодавство України": [Веб-сайт]. Київ, 2019 р. URL: https://zakon.rada.gov.ua/laws/show/667-2015-\%D0\%BF (дата звернення: 5.08.2019).

13. Про державну підтримку сільського господарства України: Закон України № 771/97-ВР за станом на 15.08.2018 p. // Верховна Рада України "Законодавство України": [Веб-сайт]. Київ, 2019 p. URL: https://zakon.rada.gov.ua/laws/show/1877-15 (дата звернення: 5.08.2019).

14. Міністерство фінансів України: [Веб-сайт]. Київ, 2019 p. URL: https://www.minfin.gov.ua/ (дата звернення: 5.08.2019).

15. Статистичний збірник «Статистичний щорічник України за 2016 рік» / Державна служба статистики України. Київ, 2017. 610 с.

16. Статистичний збірник «Наукова та інноваційна діяльність України 2015 рік» / Державна служба статистики України. Київ, 2016. 257 с.

Стаття надійшла 10.08.2019

Стаття прийнята до друку 24.08.2019

Доступно в мережі Internet 16.10.2019

\author{
Дьяченко Ю.В. \\ к.э.н.,старший преподаватель \\ кафедра менеджмента и логистики \\ Одесская национальная академия пищевых технологий \\ ул. Канатная, 112, г. Одесса, Украина, 65039 \\ E-mail: ypogarchuk@gmail.com \\ ORCID ID: 0000-0002-8754-3256
}

\section{АНАЛИЗ ВЛИЯНИЯ МАКРОФАКТОРОВ ВНЕШНЕЙ СРЕДЫ НА ДЕЯТЕЛЬНОСТЬ МЯСОПЕРЕРАБАТЫВАЮЩИХ ПРЕДПРИЯТИЙ УКРАИНЫ}

В статье рассмотрено состояние и динамика изменений политико-правового, экономического, социально-демографического, технологического макрофакторов внешней среды, оказывающих влияние на 
деятельность мясоперерабатывающих предприятий Украины. Для систематизации описанных макрофакторов использована методика построения матрицы PEST-анализа. Среди основных политико-правовых факторов можно выделить следующие: - нестабильная политическая ситуация, - потеря территориальной целостности и тем самым производственных мощностей и рынков сбыта, - кризис в отношениях с Российской Федерацией, - подписание Соглашения об ассоциации с EC за продолжение евроинтеграционных процессов, - изменения в налоговом законодательстве - необходимость адаптации законодательства Украины в соответствии с требованиями ЕС, - обязательное внедрение системы НАССР на мясоперерабатывающих предприятиях, - разработка новых стандартов, регламентирующих деятельность мясоперерабатывающих предприятий. К экономическим фракторам следует отнести: - отмена спецрежима налогообложения предприятий, занимающихся разведением животных и производством мяса (предоставляется бюджетная дотация), - девальвация национальной валюты, - низкая покупательная способность населения, - высокий уровень безработицы, - высокий индекс инфляции, - сокращение реальных доходов населения, - продовольственное эмбарго со стороны Российской Федерации, - наличие квоты на экспорт в ЕС мяса отечественного производства, которое освобождается от уплаты пошлины, -активизация Азиатского и Африканского направления ВЭД, - тенденция к сокращению рынка мяса и мясопродуктов. Исследование социально-демографического фактора позволило выявить: - уменьшение численности населения, снижение уровня рождаемости и повышение смертности населения, - ухудшение здоровья нации, - высокая доля пожилых людей в возрастной структуре населения, - отток высококвалифицированных кадров с высшим образованием за границу. Технологический фрактор можно охарактеризовать следующим образом: - низкий уровень инновационной активности предприятий пищевой промышленности, - слабое фринансирование инновационной деятельности предприятий государством, - осуществляется разработка новых видов продукции, - осуществляется разработка новых технологических процессов (малоотходных, ресурсосберегающих).

Ключевые слова: мясоперерабатывающая отрасль Украины, мясоперерабатывающие предприятия, внешняя среда, макрофакторы.

Diachenko Yu.

Ph.D., Assistant

Department of Management and Logistics

Odessa National Academy of Food Technologies

Kanatna str., 112, Odesa, Ukraine, 65039

E-mail: ypogarchuk@gmail.com

ORCID ID: 0000-0002-8754-3256

\section{ANALYSIS OF THE INFLUENCE OF ENVIRONMENTAL MACRO- FACTORS ON THE ACTIVITY OF MEAT PROCESSING ENTERPRISES IN UKRAINE}

The article reviewed the state and dynamics of changes in the politico-legal, economic, sociodemographic, technological environmental macro-factors that influence the activity of meat processing enterprises in Ukraine. To systematize the described macro-factors, the PEST analysis matrix construction technique was used. Among the main politico-legal factors, the following can be distinguished: - unstable political situation, - loss of territorial integrity and thus production capacities and markets, - crisis in relations with the Russian Federation, the signing of the Association Agreement with the EU for the continuation of the European integration processes, changes in tax legislation, - necessity to adapt the legislation of Ukraine in accordance with EU requirements, mandatory implementation of the HACCP system in meat processing enterprises; - development of new standards regulating the activity of meat processing enterprises. The economic factors include: - abolition of the special tax regime for enterprises engaged in animal breeding and meat production (the budget subsidy is provided), - devaluation of the national currency, - low purchasing power of the population, - high unemployment rate, - high inflation index, - reduction in real incomes of the population, -food import embargo by the Russian Federation, the presence of quotas for export of domestically produced meat to the EU, which is exempt from payment of fees, -activation of the Asian and African areas of External Economic Activity (EEA), - tendency to reduce the market for meat and meat products. The study of the socio-demographic factor revealed: - dwindling population, decrease in the birth rate and an increase in mortality, - deterioration in the health of the nation, - high proportion of elderly people in the age structure of the population, - outflow of highly-qualified personnel with higher education abroad. The technological factor can be characterized as follows: - low level of innovation activity of food industry enterprises, - poor financing of innovation activity of enterprises by the state, - new types of products are being developed; - new technological processes (low-waste, resource-saving) are being developed.

Key words: meat processing industry of Ukraine, meat processing enterprises, external environment, macro-factors. 


\section{References}

1. Porter, M. (2010). Konkurentsiia. Moscow: "Viliams".

2. Tompson, A. A., \& Striklend, A. Dzh. (2009). Strategicheskii menedzhment. Moscow: Viliams.

3. Ansoff, I. (2012). Strategicheskoe upravlenie. Retrieved August 1, 2019, from https://gtmarket.ru/laboratory/basis/4155.

4. Kotler, F. (2011). Marketing menedzhment. (S. G. Bozhuk, Trans.). SPb: Piter.

5. Lamben, Zh. Zh. (1996). Strategicheskii marketing. SPb: Nauka.

6. Fatkhutdinov, R. A. (2004). Upravlenie konkurentosposobnostiu organizatsii. Moscow: Eksmo.

7. Pavlova, V. A. (2006). Konkurentospromozhnist pidpryiemstva: otsinka i stratehiia zabezpechennia. D.: DUEP.

8. Balabanova, L. V., \& Krivenko, A. V. (2004). Upravlenie konkurentosposobnostiu predpriiatii na osnove marketinga. D.: Don GUET im. M. Tugan-Baranovskogo.

9. Pozharchuk, Yu. V. (2012). Faktory, shcho vplyvaiut na konkurentospromozhnist pidpryiemstva. In Aktualni dosiahnennia yevropeiskoi nauky (materialy VIII mizhnar. nauk.-prakt. konf., pp. 90-91). Sofiia.

10. Diachenko, Yu. V. (2017). Pravove zabezpechennia konkurentospromozhnosti produktsii m'iasopererobnykh pidpryiemstv Ukrainy na yevropeiskomu rynku. Ekonomika Kharchovoi Promyslovosti, 9(4), 4348. doi: 10.15673/fie.v9i4.742

11. Pro osnovni pryntsypy ta vymohy do bezpechnosti ta yakosti kharchovykh produktiv: Zakon Ukrainy № 771/97-VR za stanom na 06.08.2019 r. (2019). Retrieved August 5, 2019, from https://data.rada.gov.ua/laws/show/771/97-вp

12. Pro zatverdzhennia Polozhennia pro Derzhavnu sluzhbu Ukrainy z pytan bezpechnosti kharchovykh produktiv ta zakhystu spozhyvachiv: Postanova KMU №667 za stanom na 30.03.2019 r. (2019). Retrieved August 5, 2019, from https://zakon.rada.gov.ua/laws/show/667-2015-п.

13. Pro derzhavnu pidtrymku silskoho hospodarstva Ukrainy: Zakon Ukrainy № 771/97-VR za stanom na 15.08.2018 r. (2018). Retrieved August 5, 2019, from https://zakon.rada.gov.ua/laws/show/1877-15.

14. Ministerstvo finansiv Ukrainy. (2019). Retrieved August 5, 2019, from https://www.minfin.gov.ua/.

15. Derzhavna sluzhba statystyky Ukrainy. (2017). Statystychnyi shchorichnyk Ukrainy za 2016 rik. Kyiv.

16. Derzhavna sluzhba statystyky Ukrainy. (2016). Naukova ta innovatsiina diialnist Ukrainy 2015 rik. Kyiv.

Received 10 August 2019

Approved 24 August 2019

Available in Internet 16.10.2019

Цитування згідно ДСТУ 8302:2015

Дьяченко Ю.В. Аналіз впливу макрофакторів зовнішнього середовища на діяльність м'ясопереробних підприємств України // Економіка харчової промисловості. 2019. Т.11, вип. 3. С. 33-39. doi: 10.15673/fie.v11i3.1459

Cite as APA style citation

Diachenko, Yu. (2019). Analysis of the influence of environmental macro-factors on the activity of meat processing enterprises in Ukraine.

Food Industry Economics, 11(3), 33-39. doi: 10.15673/fie.v11i3.1459 